\title{
Evaluasi Kualitas Kesiapan Belajar Online Mahasiswa Baru Program Studi Manajemen Dakwah IAIN Pontianak
}

\author{
Abdullah Syifa \\ Program Studi Manajemen Dakwah, IAIN Pontianak \\ email: abdullah.syifa@iainptk.ac.id
}

(Received: 28 April 2021/ Accepted: 30 Mei 2021 / Published Online: 20 Juni 2021)

\begin{abstract}
Abstrak
Program Studi Manajemen Dakwah IAIN Pontianak saat ini memberlakukan pembelajaran secara online. Tentu pelaksanaannya tidaklah mudah, terlebih bagi mahasiswa baru. Meraka harus siap mengikuti pembelajaran secara online. Kondisi tersebut menarik untuk dievaluasi kualitas kesiapannya. Tujuan dari penelitian ini adalah untuk mengevaluasi kualitas kesiapan belajar online mahasiswa baru 2020/2021 Program Studi Manajemen Dakwah IAIN Pontianak dengan menggunakan pendekatan kuantitatif. Populasi penelitian ini adalah seluruh mahasiswa baru Program Studi Manajemen Dakwah IAIN Pontianak tahun 2020/2021. Teknik sampling yang digunakan dalam penelitian ini adalah total sampling, dimana seluruh anggota populasi dijadikan sebagai sampel penelitian. Data penelitian dikumpulkan dengan menggunakan instrumen tentang skala kesiapan pembelajaran online. Analisis data dilakukan dengan dua tahapan, yakni data dianalisis secara deskriptif kuantitatif presentase dan membandingkannya dengan kriteria kategori ketercapaian. Hasil penelitian ini adalah bahwa nilai rerata dimensi kepercayaan diri dalam menggunakan komputer ataupun internet untuk kegiatan pembelajaran sebesar 8,77. Rerata nilai untuk pembelajaran secara mandiri sebesar 17,77. Nilai rerata sebesar 8,95 dimiliki oleh dimensi kontrol pembelajar dalam konteks online. Dimensi motivasi belajar dalam konteks online memiliki rerata 14,41 , dan dimensi kepercayaan diri dalam melakukan komunikasi secara online memiliki nilai rerata 10,28. Kesimpulannya adalah masing-masing dimensi tersebut secara berurut adalah berkategori kurang, baik, kurang, baik, dan kurang.
\end{abstract}

Kata kunci: Evaluasi, Kesiapan Belajar Online, Mahasiswa Baru

\begin{abstract}
IAIN of Pontianak Dakwah Management Study Program is currently doing online learning. The implementation is surely difficult, especially for the new students. They need to be prepared in following the online learning. This condition is attracting the interest to evaluate the preparation quality. The purpose of this research is to evaluate the preparation quality of online learning the new students in IAIN of Pontianak Dakwah Management Study Program using the quantitative approach. The population of this research is all students from in IAIN of Pontianak Dakwah Management Study Program. The sampling technique used in this research is the total-sampling, where all the populations are used as the sample of research. Data collecting use the instrument for online learning preparation scale. Data analysis is conducted in two stages, where the data analysed in percentage quantitative descriptive and comparison with achievement category criteria. The results of this research show the median value of confidence dimension in using computer or the Internet for learning is 8,77. Median value for independent learning is 17,77. 8,95 are for students' control dimension in the online-context. The learning motivation dimension in the online-context with 14,41 value, and confidence dimension in communicating online is 10,28 value.
\end{abstract}

Keywords: Evaluation, Online Learning Readiness, New Students 


\section{PENDAHULUAN}

Dampak dari mewabahnya virus Covid-19 adalah diterapkannya teknologi dalam proses pembelajaran. Hal ini dikarenakan berlakunya kebijakan atas pembatasan secara sosial dan kontak fisik guna memutus penyebaran virus Covid-19. Penerapan teknologi yang berbasis digital dalam berbagai aktivitas pembelajaran selama pandemi Covid-19 dapat menggunakan beberapa aplikasi diantaranya Whatssap, Zoom Meeting, Google Classroom, dan juga E-Learning (Widiyono, 2020). Kondisi tersebut dengan diterapkannya pembelajaran secara online dapat diukur dengan skala kesiapan belajar secara online (Hung, Chou, Chen, \& Own, 2010). Skala ini terdiri dari beberapa dimensi yakni kepercayaan diri dalam menggunakan komputer ataupun internet untuk kegiatan pembelajaran, pembelajaran secara mandiri, kontrol pembelajar dalam konteks online, motivasi belajar dalam konteks online, dan kepercayaan diri dalam melakukan komunikasi secara online.

Percaya diri adalah keyakinan yang terdapat pada diri pribadi dalam memiliki kemampuan dan potensi tertentu. Fitrahnya, setiap pribadi memiliki rasa percaya diri, namun antara pribadi satu dengan yang lainnya memiliki kadar percaya diri yang berbeda-beda Percaya diri secara operasional didefinisikan sebagai keyakinan bahwa seseorang dapat berhasil dalam melakukan tugas yang diberikan. Semakin tinggi percaya diri seseorang, maka semakin untuk berhasil dalam suatu tugas. Seseorang dengan percaya diri rendah lebih cenderung mengurangi usaha mereka atau mudah untuk menyerah. Sementara mereka yang memiliki percaya diri tinggi akan berusaha lebih keras untuk menghadapi tantangan (Triningtyas, 2016).

Pembelajaran mandiri adalah proses di mana individu mengambil inisiatif dengan atau tanpa bantuan orang lain, dalam mendiagnosis kebutuhan belajar mereka, merumuskan tujuan pembelajaran, mengidentifikasi materi sumber daya untuk belajar, memilih dan menerapkan strategi pembelajaran yang tepat, dan mengevaluasi hasil pembelajaran, serta mereka tanggung jawab atas kendali belajar untuk mereka sendiri (Humaira \& Hurriyah, 2018). Belajar secara mandiri ditandai dengan adanya inisiatif aktivitas belajar dengan adanya bantuan orang lain ataupun tanpa bantuan orang lain (Oishi, 2020).

Kontrol diri mengacu pada kemampuan orang dalam menekan atau menghambat perilaku atau tanggapan dengan sengaja dan secara sadar terhadap aktivitas yang dianggap kurang penting. Kontrol diri yang baik akan membuat individu berperilaku disiplin. Disiplin inilah yang akan mencerminkan ketaatan dan ketertiban terhadap aturan, regulasi dan nilainilai yang berlaku di institusi pendidikan (Adlya, Yusuf, \& Effendi, 2020). Penerapan kedisiplinan ditunjukkan dengan dorongan dan kontrol yang kuat kepada individu dalam menyalurkan emosi dan tingkah lakunya. Individu yang berdisiplin adalah individu yang memiliki kemampuan untuk mengatur dan mengarahkan diri sebagaimana mestinya (McKinney, Brown, \& Malkin, 2018).

Motivasi memiliki peran penting untuk mendorong seseorang agar aktif melakukan sesuatu (Santoso, Amin, Sumitro, \& Lukiati, 2017). Tingkat motivasi yang biasa saja tidak cukup untuk mencapai tingkat keberhasilan dalam jenjang prestasi akademis dan karier. Dibutuhkan motivasi yang kuat untuk bertahan dalam mengejar prestasi akademik (Gopalan, Bakar, \& Zulkifli, 2020). Motivasi belajar memegang peranan penting dalam memberikan semangat dalam melakukan kegiatan pembelajaran. Hal tersebut tentunya akan mendorong mahasiswa untuk meningkatkan hasil belajarnya. Apabila motivasi belajar rendah, hal ini tentunya tidak akan menimbulkan dorongan dan rasa semangat untuk belajar. Dampak yang paling terlihat adalah hasil belajar mahasiswa yang cenderung rendah (Alhadi \& Nanda Eka Saputra, 2017).

Terjalinnya komunikasi di kelas online akan membuat pengalaman belajar siswa lebih bermakna dan itu dapat membantu mahasiswa tetap terhubung selama proses pembelajaran 
(Alawamleh, Al-Twait, \& Al-Saht, 2020). Komunikasi dan pengajaran yang mengacu pada komunikasi kelas diartikan sebagai kompleksitas interaksi guru-siswa selama proses pengajaran di dalam dan di luar kelas, termasuk perilaku verbal dan non-verbal serta semua faktor lain yang mempengaruhinya (Kareva, 2017).

Pelaksanaan pembelajaran secara online tersebut tidaklah mudah, terlebih bagi mahasiswa baru. Hasil penelitian oleh Sadikin dan Hamidah menyebutkan bahwa yang menjadi tantangan tersendiri dari pembelajaran online adalah lemahnya pengawasan dalam aktivitas pembelajaran, sinyal yang tidak stabil terutama di daerah pelosok, dan biaya kouta yang menjadi beban karena terhitung mahal (Sadikin \& Hamidah, 2020). Lebih lanjut Argaheni menyebutkan bahwa pembelajaran secara online berdampak negatif secara langsung pada mahasiswa pada beberapa hal, pertama, mahasiswa masih harus menyesuaikan dengan sistemnya. Kedua, mahasiswa menjadi lebih pasif dalam perkuliahan. Ketiga, konsep materi selama perkuliahan cenderung menumpuk, sehingga tidak kurang bermanfaat. Keempat, membuat mahasiswa mengalami stress belajar (Argaheni, 2020).

Hasil penelitian yang telah diungkapkan diatas tentunya juga memungkinkan akan berdampak sama pada mahasiswa baru di Program Studi Manajemen Dakwah IAIN Pontianak. Mahasiswa baru merupakan peserta didik yang baru saja mengenal dunia kampus. Mereka masih harus beradaptasi dengan lingkungan kampus, kondisi kampus, dan juga yang terpenting mahasiswa baru harus mampu beradaptasi dengan sistem pembelajaran kampus yang saat ini dengan sistem online. Sehingga dalam kondisi tersebut mahasiswa baru diharapkan memiliki kesiapan dalam berbagai hal terutama kesiapan dalam mengikuti pembelajaran secara online selama perkuliahan berlangsung. Dengan beberapa paparan diatas maka peneliti tertarik untuk mengukur dan mengevaluasi kesiapan pembelajaran secara online pada mahasiswa baru di Program Studi Manajemen Dakwah IAIN Pontianak. Penelitian ini diharapkan mampu memberikan informasi yang aktual dalam perbaikan proses pembelajaran secara online di Program Studi Manajemen Dakwah IAIN Pontianak.

\section{METODE}

Penelitian ini menggunakan pendekatan kuantitatif dengan desain penelitian evaluasi. Desain penelitian evaluasi dipilih karena pada penelitian ini akan membandingkan antara proses yang telah dilaksanakan dengan kriteria yang telah ditentukan (Kantun, 2017). Penelitian ini dilakasanakan pada Program Studi Manajemen Dakwah IAIN Pontianak. Waktu pelaksanaannya pada bulan Desember 2020. Populasi dalam penelitian ini adalah mahasiswa baru tahun akademik 2020/2021. Jumlah populasi dalam penelitian ini sebanyak 39 mahasiswa baru. Teknik sampling yang digunakan dalam penelitian ini adalah total sampling, dimana peneliti menggunakan seluruh anggota populasi sebagai anggota sampel penelitian.

Penelitian ini menggunakan analisis deskriptif kuantitatif (Amri, Uska, \& Arianti, 2018; Uska \& Wirasasmita, 2018). Penelitian ini memiliki beberapa tahapan, pertama, penentuan instrumen penelitian. Data penelitian dikumpulkan dengan menggunakan instrumen tentang skala kesiapan pembelajaran online (Hung et al., 2010; Kholisho \& Marfuatun, 2020). Skala tersebut memuat beberapa komponen yang akan mengukur terkait dengan kepercayaan diri dalam menggunakan komputer ataupun internet untuk kegiatan pembelajaran, pembelajaran secara mandiri, kontrol pembelajar dalam konteks online, motivasi belajar dalam konteks online, dan kepercayaan diri dalam melakukan komunikasi secara online. Dimensi kepercayaan diri dalam menggunakan komputer ataupun internet untuk kegiatan pembelajaran dimaknakan sebagai sejauhmana mahasiswa dengan keyakinan atas dirinya sendiri sebagai pembelajar untuk melakukan pembelajaran secara online. Dimensi pembelajaran secara mandiri menitikberatkan bahwa selain melakukan peembelajaran secara 
online ditengah kondisi pandemi, mahasiswa baru juga diharapkan mampu melakukan pembelajaran secara mandiri.

Dimensi kontrol pembelajar dalam konteks online mengarah pada mahasiswa untuk dapat melakukan kontrol diri selama perkuliahan berlangsung. Hal ini dilakukan agar mahasiswa tetap fokus pada materi perkuliahan, dan tidak terganggu pada beberapa aktivias seperti chating, browsing dan memeriksa notifikasi pada akun sosial media. Pada dimensi motivasi belajar dimaksudkan untuk mengukur semangat dalam keikutsertaan pada kegiatan pembelajaran. Dimensi kepercayaan diri dalam melakukan komunikasi secara online ditujukan untuk mengukur sejauhmana aktivitas komunikasi dua arah antara dosen dengan mahasiswa, mahasiswa dengan dosen, ataupun juga antar mahasiswa.

Tahapan kedua penelitian ini, menyusun rancangan perhitungan bobot dan kategorisasi penilaian. Penelitian ini menggunakan skala Likert dengan 4 pilihan alternatif yakni 1 untuk sangat tidak setuju, 2 untuk tidak setuju, 3 untuk setuju, dan 4 untuk sangat setuju. Adapun kriteria kategori hasil penelitian adalah sebagai berikut yang dapat dilihat pada tabel 1.

Tabel 1. Kategori Hasil Perhitungan

\begin{tabular}{cc}
\hline Skor & Kategori \\
\hline $\mathbf{X} \geq \overline{\mathbf{x}}+\mathbf{1 . S B x}$ & Sangat Baik \\
$\overline{\mathbf{x}}+\mathbf{1 . S B x}>\mathbf{X} \geq \overline{\mathbf{x}}$ & Baik \\
$\overline{\mathbf{x}}>\mathbf{X} \geq \overline{\mathbf{x}}-\mathbf{1 . S B x}$ & Kurang \\
$\mathbf{X}<\overline{\mathbf{x}}-\mathbf{1 . S B x}$ & Sangat Kurang \\
\hline
\end{tabular}

Tahap ketiga, pengumpulan data penelitian dari subjek, yakni mahasiswa baru 2020/2021 Program Studi Manajemen Dakwah IAIN Pontianak. Strategi yang dilakukan adalah dengan menyebar kuesioner melalui google form. Tahap keempat, yakni analisis data penelitian. Analisis data dilakukan dengan dua tahapan, yakni data dianalisis secara deskriptif kuantitatif presentase dan membandingkannya dengan kriteria kategori ketercapaian. Tahapan yang dilakukan pada analisis deskriptif kuantitatif persentase. Tahapan kategorisasi data dilakukan dengan membandingkan kriteria hasil penelitian dengan data hasil penelitian, serta menginterpretasikannya ke makna kualitatif.

\section{HASIL DAN PEMBAHASAN}

Hasil

Hasil penelitian ditampilkan dalam bentuk tabel data atas lima komponen yang telah diukur terkait dengan kesiapan pembelajaran secara online. Adapun data mengenai kepercayaan diri dalam menggunakan komputer ataupun internet untuk kegiatan pembelajaran tersaji pada tebel 2 .

Tabel 2. Kepercayaan Diri dalam Menggunakan Komputer ataupun Internet untuk Kegiatan Pembelajaran

\begin{tabular}{ccc}
\hline Kategori & Fi & \% \\
\hline Sangat Baik & 1 & 2.56 \\
Baik & 5 & 12.82 \\
Kurang & 32 & 82.05 \\
Sangat Kurang & 1 & 2.56 \\
Total & 39 & 100 \\
\hline
\end{tabular}

Berdasarkan tabel 2, dapat diketahui bahwa 82,05\% atau 32 mahasiswa baru Program Studi Manajemen Dakwah memiliki kepercayaan diri yang kurang dalam menggunakan 
komputer ataupun internet untuk kegiatan pembelajaran. Mahasiswa yang memiliki kategori sangat baik dan sangat kurang nilai persentasenya adalah 2,56\% atau hanya 1 orang saja dari total keseluruhan 39 mahasiswa dimasing-masing kategori tersebut. Sedangkan mahasiswa yang berkategori baik memiliki nilai frekuensi 5 mahasiswa atau 12,82\%.

Tabel 3. Pembelajaran Secara Mandiri

\begin{tabular}{ccc}
\hline Kategori & $\mathbf{F i}$ & $\boldsymbol{\%}$ \\
\hline Sangat Baik & 12 & 30.77 \\
Baik & 24 & 61.54 \\
Kurang & 1 & 2.56 \\
Sangat Kurang & 2 & 5.13 \\
Total & 39 & 100.00 \\
\hline
\end{tabular}

Tabel 3 merupakan tabel yang menggambarkan tentang kondisi pembelajaran yang dilakukan secara mandiri. Informasi yang dapat disampaikan dari tabel 2 diatas adalah 61,54\% atau 24 mahasiswa baru Program Studi Manajemen Dakwah memiliki kategori baik dalam pembelajaran secara mandiri. 12 mahasiswa (30,77\%) dapat melakukan pembelajaran secara mandiri dengan kategori sangat baik. Sedangkan mahasiswa yang berkategori kurang dan sangat kurang masing-masing nilai persentasenya adalah 2,56\% dan 5,13\% dengan nilai frekuensinya 1 dan 2 mahasiswa.

Tabel 4. Kontrol Pembelajar dalam Konteks Online

\begin{tabular}{ccc}
\hline Kategori & Fi & \% \\
\hline Sangat Baik & 3 & 7.69 \\
Baik & 10 & 25.64 \\
Kurang & 25 & 64.10 \\
Sangat Kurang & 1 & 2.56 \\
Total & 39 & 100.00 \\
\hline
\end{tabular}

Tabel 4 dapat diketahui bahwa 64,10\% atau 25 mahasiswa baru Program Studi Manajemen Dakwah berkategori kurang untuk kontrol pembelajaran dalam konteks online. Mahasiswa yang memiliki kategori sangat baik dan sangat kurang masing-masing nilai persentasenya adalah $7,69 \%$ dan $2,56 \%$, atau jika dilihat nilai frekuensinya masing-masing 3 mahasiswa untuk kategori sangat baik dan hanya 1 orang saja untuk kategori sangat kurang. Sedangkan mahasiswa yang berkategori baik memiliki nilai frekuensi 10 mahasiswa atau $25,64 \%$.

\begin{tabular}{ccc} 
Tabel 5. Motivasi Belajar dalam & Konteks Onli \\
\cline { 2 - 3 } Kategori & Fi & \% \\
\hline Sangat Baik & 19 & 48.72 \\
Baik & 15 & 38.46 \\
Kurang & 4 & 10.26 \\
Sangat Kurang & 1 & 2.56 \\
Total & 39 & 100.00 \\
\hline
\end{tabular}

Tabel 5 merupakan tabel yang menggambarkan tentang motivasi belajar dalam konteks online. Informasi yang dapat disampaikan dari tabel 4 diatas adalah 48,72\% atau 19 mahasiswa baru Program Studi Manajemen Dakwah memiliki kategori sangat baik dalam pembelajaran secara mandiri. 15 mahasiswa $(38,46 \%)$ memiliki motivasi belajaran dalam konteks online dengan kategori baik. Sedangkan mahasiswa yang berkategori kurang dan 
sangat kurang masing-masing nilai persentasenya adalah 10,26\% dan 2,56\% dengan nilai frekuensinya 4 dan 1 mahasiswa.

Berdasarkan tabel 6 dapat diketahui bahwa 41,03\% atau 16 mahasiswa baru Program Studi Manajemen Dakwah memiliki kepercayaan diri yang baik dalam melakukan komunikasi secara online pada saat pembelajaran berlangsung. Mahasiswa yang memiliki kategori sangat baik dalam melakukan komunikasi secara online pada saat pembelajaran berlangsung sebesar $25,64 \%$ atau nilai frekuensinya sebanyak 10 mahasiswa. Sedangkan mahasiswa yang berkategori kurang memiliki nilai frekuensi 12 mahasiswa atau 12,82\%, dan mahasiswa yang berkategori sangat kurang memiliki nilai frekuensi 1 mahasiswa atau 2,56\%.

Tabel 6. Kepercayaan Diri dalam Melakukan Komunikasi Secara Online

\begin{tabular}{ccc}
\hline Kategori & Fi & \% \\
\hline Sangat Baik & 10 & 25.64 \\
Baik & 16 & 41.03 \\
Kurang & 12 & 30.77 \\
Sangat Kurang & 1 & 2.56 \\
Total & 39 & 100.00 \\
\hline
\end{tabular}

Tabel 7 memberikan informasi bahwa dari kelima dimensi yang diukur dalam penelitian ini, tiga dimensi termasuk dalam kategori kurang, dan dua dimensi berkategori baik. Adapun dimensi yang berkategori kurang yakni, dimensi kepercayaan diri dalam menggunakan komputer ataupun internet untuk kegiatan pembelajaran, dimensi kontrol pembelajar dalam konteks online, dan dimensi kepercayaan diri dalam melakukan komunikasi secara online. Nilai rerata masing-masing dimensi secara berurutan yakni 8,77, 8.95, dan 10,28. Dimensi yang berkategori baik yakni pembelajaran secara mandiri dengan nilai rerata 17,77 , dan dimensi motivasi belajar dalam konteks online dengan nilai rerata 14,41.

Tabel 7 Rerata Kesiapan Pembelajaran Online

\begin{tabular}{ccc}
\hline Dimensi & Total & Kategori \\
\hline $\begin{array}{c}\text { Kepercayaan diri dalam menggunakan komputer } \\
\text { ataupun internet untuk kegiatan pembelajaran }\end{array}$ & 8,77 & Kurang \\
Pembelajaran secara mandiri & 17,77 & Baik \\
Kontrol pembelajar dalam konteks online & 8,95 & Kurang \\
Motivasi belajar dalam konteks online & 14,41 & Baik \\
Kepercayaan diri dalam melakukan komunikasi & 10,28 & Kurang \\
secara online & & \\
\hline
\end{tabular}

\section{Pembahasan}

Kepercayaan diri mahasiswa baru Manajemen Dakwah IAIN Pontianak dalam menggunakan komputer ataupun internet untuk kegiatan pembelajaran masuk dalam kategori kurang. Hal tersebut terbukti dengan nilai rerata atas respon sebesar 8,77. Kondisi tersebut tentunya menjadi perhatian bagi Program Studi Manajemen Dakwah sebagai upaya dalam perbaikan. Percaya diri adalah keyakinan yang terdapat pada diri pribadi dalam memiliki kemampuan dan potensi tertentu. Fitrahnya, setiap pribadi memiliki rasa percaya diri, namun antara pribadi satu dengan yang lainnya memiliki kadar percaya diri yang berbeda-beda (Triningtyas, 2016). Kurangnya percaya diri dalam konteks ini dapat dilatarbelakangi oleh berbagai hal diantaranya kurang familiarnya penggunaan komputer ataupun internet untuk kebutuhan belajar (Hamka, 2015). Hasil penelitian yang dilakukan oleh Hamka 
merekomendasikan bahwa perlunya peningkatan keterampilan di bidang IT bagi dosen dan juga mahasiswa. Hal tersebut dilakukan agar pembelajaran berbasis internet ataupun secara online dapat secara optimal dilakukan. Pendidikan dengan berbasis online menjadi keniscayaan seiring dengan berkembangnya peradaban dibidang teknologi informasi. Terlebih disaat ini kualitas SDM Indonesia dituntut agar mampu bersaing di masyarakat global yang sangat kompetitif (Surahman, 2019).

Dimensi kedua yang diukur pada penelitian ini adalah sejauhmana mahasiswa baru dalam melakukan pembelajaran secara mandiri. Dimensi ini menitikberatkan bahwa selain melakukan peembelajaran secara online ditengah kondisi pandemi, mahasiswa baru juga diharapkan mampu melakukan pembelajaran secara mandiri. Hal tersebut perlu dilakukan sebagai upaya pribadi sebagai seorang mahasiswa dalam meningkatkan pemahaman dan keterampilan tertentu pada perkuliahan yang telah disampaikan oleh dosen di kelas-kelas virtualnya. Pada dimensi kedua ini nilai reratanya adalah 17,77 dan termasuk pada kategori baik. Artinya, mahasiswa baru pada Program Studi Manajemen Dakwah IAIN Pontianak telah berupaya dalam mengulang dan merefleksikan atas perkulihan yang telah disampaikan oleh dosen dalam bentuk belajar secara mandiri. Hal yang telah dilakukan adalah bukti bahwa mereka memiliki tanggung jawab akademis sebagai seorang mahasiswa walaupun perkuliahan dilakukan secara daring. Tanggung jawab dalam aktivitas belajar adalah sebuah kewajiban dalam upaya menyelesaikan beberapa tugas secara tuntas dengan usaha semaksimal mungkin serta bersedia bertanggung jawab dengan apa yang telah dikerjakannya (Syafitri, 2017). Sikap tanggung jawab dan kemandirian belajar merupakan karakter yang sangat menentukan dalam pembentukan personal mahasiswa yang mempunyai kemampuan belajar sepanjang hayat (lifelong learning). Belajar secara mandiri ditandai dengan adanya inisiatif aktivitas belajar dengan adanya bantuan orang lain ataupun tanpa bantuan orang lain (Oishi, 2020).

Kondisi pembelajaran di tengah pandemi mengharuskan mahasiswa untuk melakukan kontrol diri selama perkuliahan berlangsung. Hal ini dilakukan agar mahasiswa tetap fokus pada materi perkuliahan, dan tidak terganggu pada beberapa aktivias seperti chating, browsing dan memeriksa notifikasi pada akun sosial media. Kontrol diri mengacu pada kemampuan orang dalam menekan atau menghambat perilaku atau tanggapan dengan sengaja dan secara sadar terhadap aktivitas yang dianggap kurang penting. Pengendalian diri juga diartikan sebagai kemampuan seseorang untuk mengubah tanggapan berkenaan dengan standar ideal, moral, nilai, dan harapan sosial, dalam mengejar target jangka panjang (Judistira \& Wijaya, 2017). Kontrol diri yang baik akan membuat individu berperilaku disiplin. Disiplin inilah yang akan mencerminkan ketaatan dan ketertiban terhadap aturan, regulasi dan nilai-nilai yang berlaku di institusi pendidikan (Adlya et al., 2020). Penerapan kedisiplinan ditunjukkan dengan dorongan dan kontrol yang kuat kepada individu dalam menyalurkan emosi dan tingkah lakunya. Individu yang berdisiplin adalah individu yang memiliki kemampuan untuk mengatur dan mengarahkan diri sebagaimana mestinya (McKinney et al., 2018). Mengingat kontrol belajar mahasiswa baru Program Studi Manajemen Dakwah IAIN dalam konteks belajar online masih berkategori rendah yakni nilai rerata 8,95, maka perlu adanya pembekalan dan arahan pada mahasiswa baru agar kontrol diri mereka selama pembelajaran online dapat lebih ditingkatkan.

Walaupun kontrol diri mahasiswa baru selama perkuliahan berlangsung pada Program Studi Manajemen Dakwah IAIN Pontianak tergolong kurang, namun motivasi belajar mereka dalam konteks online tergolong baik. Hal ini dibuktikan dengan nilai rerata dari data yang terkumpul adalah 14,41. Tentunya ini merupakan hal yang positif dan terus untuk ditingkatkan. Motivasi adalah bagian kompleks dari psikologi dan perilaku manusia yang memengaruhi bagaimana individu memilih untuk menginvestasikan waktu mereka, berapa banyak energi yang mereka gunakan dalam tugas tertentu, bagaimana mereka berpikir dan 
merasakan tugas, dan berapa lama mereka bertahan dalam tugas tersebut (Filgona, Sakiyo, Gwany, \& Okoronka, 2020). Motivasi tercermin dalam pilihan tugas belajar mahasiswa, waktu dan tenaga yang mereka curahkan untuk mereka, ketekunan mereka dalam tugas belajar, dan dalam mengatasi kendala yang mereka hadapi dalam proses pembelajaran (Bakar, 2014). Motivasi dapat dipahami sebagai apa yang mendorong mahasiswa untuk leluasa mencurahkan waktunya pada suatu kegiatan tertentu. Dorongan ini tidak hanya untuk memulai aktivitas tetapi juga untuk terus mengerjakannya sepanjang hidup mereka. Namun, motivasi sifatnya lebih individual dan pribadi dan akan memiliki perbedaan dalam setiap konteks individu. Motivasi atau dorongan ini dapat berasal dari siswa itu sendiri atau dari rangsangan eksternal (Redondo \& Martin, 2015). Motivasi belajar memegang peranan penting dalam memberikan semangat dalam melakukan kegiatan pembelajaran. Hal tersebut tentunya akan mendorong mahasiswa untuk meningkatkan hasil belajarnya. Apabila motivasi belajar rendah, hal ini tentunya tidak akan menimbulkan dorongan dan rasa semangat untuk belajar. Dampak yang paling terlihat adalah hasil belajar mahasiswa yang cenderung rendah (Alhadi \& Nanda Eka Saputra, 2017).

Selama pembelajaran berlangsung, aktivitas komunikasi dua arah diharapkan tetap terjadi antara dosen dengan mahasiswa, mahasiswa dengan dosen, ataupun juga antar mahasiswa. Terjadinya komunikasi dua arah terkait dengan pembahasan materi perkuliahan menandakan bahwa aktivitas pembelajaran berlangsung secara baik. Kepercayaan diri dalam melakukan komunikasi secara online pada penelitian ini terkait dengan merasa yakin (bisa dan mampu) dalam menggunakan alat online seperti email, untuk berkomunikasi secara efektif dengan orang lain termasuk dosen, terbiasa dalam mengekspresikan diri (seperti emosi dan humor) melalui teks di media sosial, dan juga merasa percaya diri dalam memposting pertanyaan pada diskusi online. Kategori capaian atas kepercayaan diri dalam melakukan komunikasi secara online masih tergolong rendah yakni dengan nilai rerata 10,28. Artinya adalah mahasiswa baru pada Program Studi Manajemen Dakwah IAIN Pontianak masih perlu pembenahan dalam membangun kepercayaan diri pada aktivitas komunikasi selama pembelajaran online berlangsung. Temuan ini senada dengan Mayende dalam studinya yang menyebutkan bahwa ternyata hanya $20 \%$ saja dari keseluruhan peserta aktif mendominasi interaksi pembelajaran online, dan selebihnya (80\%) adalah mahasiwa pasif dalam melakukan komunikasi. Temuan lebih lanjut menyebutkan bahwa sebagian besar komunikasi tidak berkaitan dengan pembelajaran, melainkan masalah teknis (26\%), basa-basi (29\%), berbagi pengalaman (16\%), dan dorongan (11\%). Hanya $10 \%$ yang terkait dengan konten pembelajaran (Mayende, Prinz, \& Isabwe, 2017). Alawamleh menerangkan bahwa tujuan komunikasi selama pembelajaran secara online sama dengan tujuan komunikasi tatap muka seperti biasa, diantaranya menjalin ikatan, bertukar informasi, mendengar dan memahami materi selama proses pembelajaran berlangsung. Terjalinnya komunikasi di kelas online akan membuat pengalaman belajar siswa lebih bermakna dan itu dapat membantu mahasiswa tetap terhubung selama proses pembelajaran (Alawamleh et al., 2020). Lebih tegas dijelaskan bahwa komunikasi online di lingkungan akademik memiliki beberapa tujuan diantaranya, berkomunikasi, berbagi gambar, pesan, ide, berpendapat secara pribadi, memposting, mengunduh, memvisualisasikan informasi dan mengirim/menerima beberapa dokumen (Avram, 2015).

\section{SIMPULAN}

Hasil perhitungan yang telah dilakukan dengan merujuk pada kategori penilaian disimpulkan bahwa dimensi kepercayaan diri dalam menggunakan komputer ataupun internet untuk kegiatan pembelajaran, dimensi kontrol pembelajar dalam konteks online, dan dimensi kepercayaan diri dalam melakukan komunikasi secara online berkategori kurang. Nilai rerata 
masing-masing dimensi secara berurutan yakni 8,77, 8.95, dan 10,28. Dimensi yang berkategori baik yakni pembelajaran secara mandiri dengan nilai rerata 17,77 , dan dimensi motivasi belajar dalam konteks online dengan nilai rerata 14,41. Secara keseluruhan belum bisa dikatakan bahwa mahasiswa baru Program Studi Manajemen Dakwah telah benar-benar siap dalam melakukan pembelajaran secara online. Perlu adanya upaya-upaya yang konkrit agar ketidaksiapan dalam melakukan pembelajaran secara online ini tidak terulang. Rekomendasi yang dapat diusulkan untuk perbaikannya adalah bahwa perlu adanya bimbingan berkala sebagai pengetahuan dan bekal awal bagi mahasiswa baru tentang bagaimana seharusnya perkuliahan secara online dengan baik. Hal tersebut dapat diinisiasi oleh program studi sebagai unit yang bersentuhan langsung dengan mahasiswa baru. Program studi juga selayaknya bisa memfasilitasi mahasiswa baru dalam bentuk diskusi ringan. Kegiatan ini dilakukan agar mereka bisa memaparkan apa saja yang menjadi kendala selama perkuliahan online berlangsung. Selain itu, kegiatan tersebut sebagai penguat dan memberi semangat agar mereka tetap merasa nyaman dan tidak merasa stress belajar.

\section{REFERENSI}

Adlya, S. I., Yusuf, A. M., \& Effendi, M. (2020). The contribution of self control to students' discipline. Journal of Counseling and Educational Technology, 3(1), 1-5. https://doi.org/10.32698/0791

Alawamleh, M., Al-Twait, L. M., \& Al-Saht, G. R. (2020). The Effect of Online Learning on Communication Between Instructors and Students During Covid-19 Pandemic. Asian Education and Development Studies, (August). https://doi.org/10.1108/AEDS-06-20200131

Alhadi, S., \& Nanda Eka Saputra, W. (2017). The Relationship between Learning Motivation and Learning Outcome of Junior High School Students in Yogyakarta. Yogyakarta International Conference on Educational Management/Administration and Pedagogy, 66, 138-141. https://doi.org/10.2991/yicemap-17.2017.23

Amri, Z., Uska, M. Z., \& Arianti, B. D. D. (2018). Analisis Usability Website Universitas Hamzanwadi terhadap Kepuasan Pengguna dengan Menggunakan User Satisfaction Model. EDUMATIC: Jurnal Pendidikan Informatika, 2(1), 15-23. https://doi.org/10.29408/edumatic.v2i1.842

Argaheni, N. B. (2020). Sistematik Review: Dampak Perkuliahan Daring Saat Pandemi COVID-19 Terhadap Mahasiswa Indonesia. PLACENTUM: Jurnal Ilmiah Kesehatan Dan Aplikasinya, 8(2), 99-108. https://doi.org/10.20961/placentum.v8i2.43008

Avram, E. M. (2015). The Importance of Online Communication in Higher Education. Network Intelligence Studies, 3(05), 15-21.

Bakar, R. (2014). The Affect Of Learning Motivation On Student's Productive Competencies In Vovational High School, West Sumatera. 4(6), 722-732.

Filgona, J., Sakiyo, J., Gwany, D. M., \& Okoronka, A. U. (2020). Motivation in Learning. Asian Journal of Education and Social Studies, 10(4), 16-37. https://doi.org/10.9734/ajess/2020/v10i430273

Gopalan, V., Bakar, J. A. A., \& Zulkifli, A. N. (2020). A review of motivation theories, models and instruments in learning environment. Journal of Critical Reviews, 7(6), 554559. https://doi.org/10.31838/jcr.07.06.100

Hamka. (2015). Penggunaan Internet Sebagai Media Pembelajaran Pada Mahasiswa Iain Palu. HUNAFA: Jurnal Studia Islamika, 12(1), 95-119.

Humaira, S. A., \& Hurriyah, I. A. (2018). Students ' Perspectives Towards Self-Directed Learning Out of Classroom. International Conference on English Language Teaching, 145, 6-11. Surabaya: Atlantis Press.

Hung, M. L., Chou, C., Chen, C. H., \& Own, Z. Y. (2010). Learner readiness for online 
learning: Scale development and student perceptions. Computers and Education, 55(3), 1080-1090. https://doi.org/10.1016/j.compedu.2010.05.004

Judistira, A. A., \& Wijaya, H. E. (2017). The Role of Self-Control and Self-Adjustment on Academic Achievement. Advances in Social Science, Education and Humanities Research, 128, 122-125. Indonesia: Atlantis Press.

Kantun, S. (2017). Penelitian Evaluatif Sebagai Salah Satu Model Penelitian Dalam Bidang Pendidikan. Majalah Ilmiah Dinamika, 37(1), 15.

Kareva, V. (2017). The Influence of Classroom Communication on Student Commitment to the University. 7(26), 90-104.

Kholisho, Y. N., \& Marfuatun, M. (2020). Daya Serap Pelaksanaan Mata Kuliah Kependidikan di Tengah Pandemi Covid-19. Edumatic: Jurnal Pendidikan Informatika, 4(1), 131-140.

Mayende, G., Prinz, A., \& Isabwe, G. M. N. (2017). Improving Communication in Online Learning Systems. International Conference on Computer Supported Education, 1, 300307. https://doi.org/10.5220/0006311103000307

McKinney, C., Brown, K., \& Malkin, M. L. (2018). Parenting Style, Discipline, and Parental Psychopathology: Gender Dyadic Interactions in Emerging Adults. Journal of Child and Family Studies, 27(1), 290-301. https://doi.org/10.1007/s10826-017-0865-7

Oishi, I. R. V. (2020). Pentingnya Belajar Mandiri bagi Peserta Didik di Perguruan Tinggi. IKRA-ITH Humaniora, 4(2), 50-55.

Redondo, R. E., \& Martin, J. L. O. (2015). Motivation: The Road to Successful Learning. Profile, 17(2), 125-136.

Sadikin, A., \& Hamidah, A. (2020). Pembelajaran Daring di Tengah Wabah Covid-19. Biodik, 6(2), 109-119. https://doi.org/10.22437/bio.v6i2.9759

Santoso, A. M., Amin, M., Sumitro, S. B., \& Lukiati, B. (2017). Learning Motivation of Students During the Implementation of Lecturing Based in Silico Approach. International Journal of Research and Review, 4(9), 6-9.

Surahman, E. (2019). Integrated Mobile Learning System (Imoles) Sebagai Upaya Mewujudkan Masyarakat Pebelajar Unggul Era Digital. JINOTEP (Jurnal Inovasi Dan Teknologi Pembelajaran) Kajian Dan Riset Dalam Teknologi Pembelajaran, 5(2), 5056. https://doi.org/10.17977/um031v5i22019p050

Syafitri, R. (2017). Meningkatkan Tanggung Jawab Belajar Melalui Strategi Giving Questions and Getting Answers Pada Siswa. Jurnal Penelitian Dan Pengembangan Pendidikan, 1(2), 57-63. https://doi.org/10.23887/jppp.v1i2.12623

Triningtyas, D. A. (2016). Studi Kasus Tentang Rasa Percaya Diri, Faktor Penyebabnya Dan Upaya Memperbaiki Dengan Menggunakan Konseling Individual. Counsellia: Jurnal Bimbingan Dan Konseling, 3(1). https://doi.org/10.25273/counsellia.v3i1.239

Uska, M. Z., \& Wirasasmita, R. H. (2018). Analisis Teknologi Smartphone dalam Mendukung Kegiatan Akademis di Universitas Hamzanwadi Menggunakan Technology Acceptance Model. Edumatic: Jurnal Pendidikan Informatika, 2(2), 51-60.

Widiyono, A. (2020). Efektifitas Perkuliahan Daring (Online) pada Mahasiswa PGSD di Saat Pandemi Covid 19. Jurnal Pendidikan, 8(2), 169-177. https://doi.org/10.36232/pendidikan.v8i2.458 